\title{
The Case of the European Union Partnership and Cooperation Agreement Negotiations with Thailand
}

\author{
NAI LA MAIER-KNAPP \\ University of Canterbury \\ nnk10@uclive.ac.nz
}

\begin{abstract}
This article examines the European Union's (EU) current negotiations of the Partnership and Cooperation Agreement (PCA) with Thailand. It asks why the EU has entered into the negotiation process with this remote developing economy and provides theoretical explanations for the EU's motivations. It will give an overview of the process and discuss the issues that have emerged in the course of the negotiations and are currently pending. The article will assess the pre-negotiation phase and the obstacles during the negotiation phase that have delayed the conclusion of the process. The findings will allude to historical institutionalism and a self-devised content-context approach synthesised with William I. Zartman's insights on negotiation theory. The article argues that despite the importance of the economic dimension of the negotiations and the general prevalence of international political economy in explaining the EU's relations with Asia, this case reveals a complexity of variables that contest a purely economic lens and allow a theoretically eclectic and reflectivist understanding of the impediments, stimuli and of the process itself.
\end{abstract}

Keywords: EU, Thailand, Partnership and Cooperation Agreement, negotiation theory, socialisation, historical institutionalism

\section{Introduction}

This article presents an overview and assessment of the ongoing Partnership and Cooperation Agreement (PCA) negotiations between the European Union (EU) and Thailand. The core aim is to provide information on the notoriously opaque Thailand-EU PCA negotiations and offer some viable theoretical approaches that explain the process and offer insights into possible outcomes of the negotiations.

Six years after the EU approached Thailand to negotiate a PCA, both sides claim the process to be close to conclusion. It has been a tedious process since under Thaksin Thailand embraced the EU's suggestion of a comprehensive EU-Thailand cooperation framework that would supersede the Cooperation Agreement of 1980 between the Association of Southeast Asian Nations (ASEAN) and European Economic Community (EEC) governing Thailand's cooperation with the EU until now. Various attempts to update and renew this Cold War agreement had failed. In 
the 1990s, perceived irreconcilable differences between the "ASEAN way" and European values foreclosed any constructive dialogue on this.

The New Asia Strategy of 1994 (COM(94)314) and its revised version in 2001 (COM(2001)469) have expressed the need to develop the EU's relations with Southeast Asia. In line with this document, the European Commission (EC) issued the communication documents Creating a new dynamic in EU-ASEAN relations (COM(1996)314) and, in the following years, A new partnership with South East Asia (COM (2003) 399/4). The latter document provides the key strategy document for Southeast Asia envisaging an enhanced EU partnership after the Cooperation Agreement of 1980 had become obsolete. On the basis of this document the EC seeks to establish PCAs with individual ASEAN member states after an interregional approach proved to be infeasible. The bilateral approach avoids the inclusion of Myanmar and allows the EU to assert its stakes in what is commonly known to be the "Pacific Century" in a country-specific manner. This does not suggest that the economic dimension is the only driving force behind the EU's action.

This article will present an alternative explanation of why the process was initiated and provide theoretical insights into the interaction between the two sides on the PCA. The analysis will draw on the information shared by EU and Thai officials involved in the negotiations in ten interviews conducted between 2008 and 2010. The interviews were semi-structured and qualitative and averaged 40 minutes each. Additionally, the article is based on secondary literature in the form of online and newspaper articles. Despite the flexible format of the interviews, which allowed both sides to speak more freely and include their personal opinions, the interviewees generally adhered to the official rhetoric. With regard to validity, one needs to understand that given the small number of officials directly involved in the negotiations, there are not many officials to interview. At the time of writing, the negotiations were ongoing; thus, sources from scholarly debate are non-existent. Since the public has been denied access to the official documents, reference to EUThailand PCA official communication is impossible. Fortunately, the Council Decision on the signing of the EU-Indonesia PCA is publicly available and may serve as a reference document for getting an understanding of the types of clauses relevant to the Thai PCA, which is similar in size and content. The EC states that the

[d]isclosure of the documents would hamper the Community's decisionmaking procedures and weaken the EU's negotiation positions in the negotiations with these countries and, thereby, undermine the protection of the public interest as regards international relations. ${ }^{1}$

In this context, one has to wonder whether this opaqueness truly serves the public interest as argued by the interviewed EU officials or whether it is, in fact, an elitist means to create a fait accompli that is neither questioned nor subject to alteration by the European public. Hence, the verification of the information extracted from the interviews took place by comparing the information of the two indicated types of sources.

\footnotetext{
${ }^{1}$ External Relations Directorate General of the European Commission, Demande d'acces aux documents, 2009.
} 


\section{Overview of the Process}

Soon after the Council authorised the EC to negotiate bilateral PCAs with Indonesia, Thailand, Singapore, the Philippines, Brunei and Malaysia on 25 November 2004, the negotiation process was launched with Thailand and Singapore. In 2005, the negotiation process was in a nascent stage. Later in the year, obstacles became apparent and the momentum was lost. The first problem arose on the European side and revolved around specific systemic and internal legal matters in October 2005. As a multi-headed entity, the EU had troubles in defining the competences of the EU institutions involved. This initial impediment to the process was followed by the coup in Thailand in September 2006. The dialogue was officially suspended, but continued on an informal basis. The domestic developments in Thailand hampered and retarded the process. In the course of the negotiations, new issues emerged in response to the domestic and international developments and had to be incorporated into the treaty. The current pending clauses are concerned with the content of the document.

The following paragraphs will apply an eclectic theoretical framework to the negotiation process in order to explain why the EU and Thailand entered into negotiations and why the negotiations have been decelerated. A priori, the perseverance of both sides displays the understanding that negotiation is

the process of combining of divergent/conflicting positions through communication into a joint decision...[, that is,] a positive-sum exercise, since by definition both parties prefer the agreed outcome to the status quo (i.e., to no agreement) or to any other mutually agreeable outcome. Both sides come off better in the agreement than in the absence of the agreement, or else they would not agree. ${ }^{2}$

\section{Analytical Framework}

Framing the PCA negotiations along the lines of one theory may provide insufficient explanatory value for the entire process. The article conceptualises an eclectic approach applying a historical institutionalist (HI) lens for the rapprochement phase and constructivism, negotiation theory and a self-devised content-context distinction for the negotiation phase. It differentiates between obstacles of context and content, whereby both spheres frequently overlap and condition each other. Obstacles of content mainly originate from the wording and information of the clauses, whereas obstacles of context arise from the cultural, institutional, geographical implications of the clauses. For the negotiation process, a synthesis of negotiation theory and the content-context approach captures and localises the obstacles within the multi-tiered and -sectoral negotiation complex. This article identifies the impacting variables on the internal and external processes of the counterparts. It builds on a constructivist perspective of William I. Zartman's insights on negotiation theory and views the protagonists as social actors within an international society. ${ }^{3}$

\footnotetext{
${ }^{2}$ W. Zartman, Negotiation and Conflict Management. Essays on theory and practice, New York: Routledge, 2008, pp. 2- 54.

${ }^{3}$ For a detailed discussion on the social construction of international society see, J . Searle, The Construction of Social Reality, New York: The Free Press, 1995. and A.Wendt, Social Theory of International Politics, Cambridge: Cambridge University Press, 1999.
} 
From an HI perspective, path-dependency, maximising the utility of existing institutional arrangements to lower costs while increasing benefits and locking in actors in an institutional path of development are important premises in the prenegotiation phase. The strategy documents and cooperation agreements of the EU's external relations, with particular regard to its relations with Southeast Asia and Thailand, appear to be the drivers of EU behaviour. These documents on Southeast Asia have been "outcomes at a 'critical juncture' trigger[ing] feedback mechanisms that reinforce the recurrence of a particular pattern into the future". 4 Paul Pierson and Theda Skocpol further argue that "once actors have ventured far down a particular path, however, they are likely to find it very difficult to reverse course. Political alternatives that were once quite plausible may become irretrievably lost". ${ }^{5}$ HI considers institutions to be the shapers of future political developments. It deemphasises the role of the state and allows room for non-state actors to be included The inclusion of non-state actors is not necessarily viewed as an incremental redistribution of power away from the state. ${ }^{6}$

\section{Technicalities of the Process}

The EU's chief negotiator is the Director of Asia (except Japan and Korea) of the Directorate General for External Relations of the EC while the Thai delegation is led by the Deputy Permanent Secretary who is concerned with bilateral issues. On the EU side, negotiation guidelines for the EC are set by the Council, which has preconsensualised the mandate. The directives generally reflect toned down interests achieved by a consensus between the 27 member states. However, in some instances, there are some member states which are more dominant in having their interests and views incorporated into the consensus. ${ }^{7}$ Influence is a matter of a Member State's relative power position, or its ability to convincingly push an issue, or a combination of these two factors. The EC reverts to the Council when the directive is underachieved or when the EC may need to extend the margins in order to move on and not lose momentum with the process.

On the Thai side, the procedure is institutionally less complex since the negotiators refer horizontally to the issue-specific ministries and bargain outcomes directly according to the interests of the Thai political elite and public. In the end, the PCA will have to be ratified by the Thai Cabinet and Parliament.

4 P. Pierson and T. Skocpol, 'Historical Institutionalism in Contemporary Political Science,' in I. Katznelson and H. V. Milner (eds.), Political Science: State of the Discipline, New York: W.W. Norton, 2002, p. 699.

5 Ibid.

${ }^{6} \mathrm{~K}$. Thelen, 'Historical Institutionalism in Comparative Politics,' Annual Review of Political Science, Vol. 2, 1999, p. 383. For a detailed discussion on historical institutionalism in relation to EU integration and politics see, e.g. K.M. Anderson and E. Immergut, 'Historical Institutionalism and West European Politics,' West European Politics, Vol. 31, No. 1-2, J anuary 2008, pp. 345-69. or P. Pierson, 'The Path to European Integration. A historical institutionalist analysis,' Comparative Political Studies, Vol. 29, No. 2, April 1996, pp.123-63. or M.A. Pollack, The New Institutionalism and EC Governance: The promise and limits of institutional analysis,' Governance, Vol. 9, No. 4, October 1996, pp. 429-58.

${ }^{7}$ Interviews with EU official, General Secretariat of the Council of the European Union, 12 November 2009, Brussels, and EU official, DG RELEX (now External Action Service), 19 November 2009, Brussels, and EU official DG RELEX (now External Action Service), 20 November 2009, Brussels, and EU official, EU Delegation to Thailand, 5 December 2009, Bangkok, conducted by the author. 
The EU also has to cater to its people and, simultaneously, be congruent with its corporate and normative identity. Since the Lisbon Treaty became effective, the putative influence of the European constituencies has increased and the European Parliament enjoys more involvement in the decision-making process through codecision.

Since the start of the negotiations, there have been eight official negotiation rounds at the director level as of November 2009, with the latest one being in March that year. ${ }^{8}$ Currently, a ninth negotiation round is not scheduled, since both sides are working on the three pending issues. In between the official rounds there is regular informal, but nevertheless vital, contact on the PCA at the ambassadorial working level, paving the way for the rounds to discuss the articles of the treaty. Without these unofficial meetings, in particular, with regard to the ones by the Thai ambassador to Belgium and the EC Delegation officials to Thailand, the dialogue would have risked being stalled for longer periods and could even have lost momentum entirely, leading to stagnation. These unofficial meetings allow a presence and deeper understanding of the negotiation partners on site. The EU suspended the talks temporarily pursuant to the coup in 2006 and following the various phases of violent political clashes in Bangkok. During these difficult periods, the informal contacts between the representatives of both sides were maintained and this facilitated the advancement of the dialogue once the suspension was annulled. Thailand's political culture avoids direct rejection and confrontation. For this reason, the EU's suspension was considered culturally insensitive. An EU official contemplates

What I think is interesting is the functioning of the agreement and in terms of the application of the agreement and the possibility to suspend the agreement and there maybe we come into cultural issue, because saying that you may suspend an agreement implies that you put up an unfriendly face. This is not so much a problem because we probably have more the American style in us. From the European side, we have no difficulty talking about it. From the Thai side, they have more difficulties talking about it,...this is something to work on. ${ }^{9}$

\section{Entering into Dialogue: European Motivation}

For decades, in its capacity as an international actor, the EEC/EU, has been negotiating cooperation, framework or association agreements with third parties. These agreements have different names and generally present an exchange of

\footnotetext{
8 Interviews with EU official, General Secretariat of the Council of the European Union, 12 November 2009, Brussels, and EU official, DG RELEX (now External Action Service), 20 November 2009, Brussels, and Thai official, Ministry of Foreign Affairs, 11 December 2009, Bangkok, conducted by the author.

${ }^{9}$ Interview with EU official, DG RELEX (now External Action Service), 19 November 2009, Brussels, conducted by the author.
} 
commitments between the EU and the third parties. The EU is currently negotiating PCAs with ASEAN states, excluding Cambodia, Laos and Myanmar. In view of the EU's intrinsic institutionalisation of the outside world and the existing strategies and cooperative arrangements with Southeast Asia, the PCA with Thailand appears to be part of a historical process that has locked the EU in a specific institutional path of evolution. One Thai official explained

the European Union has this policy of trying to sign the PCA with many countries...it is a standard running policy for the European Union to do this... [and] it was only a matter of time before they mentioned it to us. ${ }^{10}$

This suggests that states may not be the sole drivers of the EU's external action, whereby $\mathrm{HI}$ possesses explanatory power to elucidate the EU's interest in a PCA with ASEAN member states. On the one hand, as previously indicated, Pierson argues that states are actors who seek to maximise their interests but may implement unanticipated policies because of the embodiment of contemporary and future policies within present institutions constraining the scope of policies. ${ }^{11}$ On the other, policies based on historically selected and narrowed down institutions may be an effective basis of policy-making having pre-excluded any ineffective option. Despite its relevance, HI may to some extent trivialise the EU's external trade agenda, which constitutes the essence of the EU's current external relations. An EU official confirms

\begin{abstract}
It is an absolute natural thing for the European Union as a free trade actor on a global scale who is a trade [partner] with Asia, with all the Asian countries.... The leverage we have as an incontournable actor on the international scene must be very big to use the leverage with those countries in order to achieve some of our non-trade goals, political goals worldwide by integrating those as conditions sine qua non in those PCAs. ${ }^{12}$
\end{abstract}

The EU is one of the top three trade partners and sources of FDI for Thailand. This demonstrates Thailand's economic dependency on the EU, in spite of a trade surplus for Thailand in the last decade. The EU has the economic leverage or bargaining power to shape the PCA negotiations to its will. However, this does not explain the EU's interest in having a PCA with Thailand since the EU's FDI to Thailand in the last decade has been on a decline and accounted for merely 3\% of the total amount invested in East Asia over the past decade. ${ }^{13}$ Southeast Asia plays a minor role to China, where the majority of EU FDI to East Asia is concentrated, that is, approximately $50 \%$ of the total FDI. The EU's proposal to Thailand to negotiate a

\footnotetext{
${ }^{10}$ Interview with Thai official, Ministry of Foreign Affairs, 11 November 2009, Bangkok, conducted by the author.

${ }^{11}$ Pierson, op. cit., p. 126.

12 Interview with EU official, General Secretariat of the Council of the European Union, 12 November 2009, Brussels, conducted by the author.

${ }^{13}$ Eurostat, European Union foreign direct investment yearbook 2007: Data 2001-2005, 2007, pp. 726. and

Thailand Board of Investment, Foreign Investment, online data retrieved on 22 March 2010, from Thailand

Board of Investment: <http://www.boi.go.th/english/about/statistics investment.asp. $>$, accessed 22 March 2010.
} 
PCA seems to conform to HI reasoning, and economic motivations to enter into dialogue with Thailand appear of marginal explanatory utility from an EU perspective, but credible from a Thai perspective.

\section{The Negotiation Phase: Obstacles of Content and Context}

The obstacles of content revolve around political and legal clauses that have been tougher to discuss than cultural, trade and other non-political matters. A Thai official claims

when they [the EU] negotiate these kind of treaties they [emphasise] [(verb altered due to request by interviewee)] political issues, you know, democracy, human rights, the rule of law, something not that tangible. In Thailand, what we are looking for is something more tangible, mainly sort of, economic benefits; more from the economic aspect, what we can gain, we are a large exporting country. ${ }^{14}$

The difference in priorities complicates the negotiation. Whilst the EU seeks a comprehensive agreement, Thailand clearly aims to gain from it, a priori, economically. According to the interviews, it appears that Thailand and the EU entered into the dialogue with different expectations of what the overall objective of this treaty should be. The Thai side clearly emphasised the economic benefits in contrast to the EU which considered the political clauses equally, if not, more important (see discussion of Article 47 below). Whereas tangibility is normally a trademark of EU institutions, it seems that, in this context, the Thai side is more focussed on this. The Thai negotiators entered into this dialogue with expectations that this legal agreement could give Thailand an advantageous trading position with the EU compared to other competitors for European market access in the region. For Thailand it is about bargaining interests. Instead, according to the Thai interviewees, the EU is bargaining norms and is pushing its normative agenda and shaping the document along the lines it envisions future cooperation to take place. This suggests that the EU is more inclined to be normative when lesser economic interests are at stake. It is noteworthy that in the Council Decision on 22 September 2009 on the signing of the PCA with Indonesia, it is expressed that "[t]he PCA will allow the EU to assume greater responsibility and influence in a region which traditionally tends to be oriented towards and influenced by China and the US."15

Given the EU's normative internal and external identity manifest in the various EU treaties, the overall political goal associated with the EU's approach is selfexplanatory. However, the EU's institutionalised value-laden identity, as it is projected onto the international level, fails to offer a profound causality and understanding of the different factors which entail the fluctuation of the EU's normative agenda in external affairs.

\footnotetext{
${ }^{14}$ Interview with Thai official, Ministry of Foreign Affairs, 11 December 2009, Bangkok, conducted by the author.

${ }^{15}$ European Commission, Proposal for a Council Decision on the signing of the Framework Agreement on comprehensive Partnership and Cooperation between the European Community and its Member States, of the one part, and the Republic of Indonesia, of the other part, 2009, p. 2.
} 
The difference in normative emphasis is usually partially explained by the different publics that the two sides have to cater to. The EU's normative actorness in the EUThailand PCA negotiations reveals the influence of its normative identity, however, it does not causally link the European public into the equation. The EU interviewees have mentioned their accountability for the PCA to the public, but the lack of publicly available documents and the minimal information shared on EU websites disassociates the process from the media and public. The EU-Thailand PCA negotiation process touches on the EU's democratic deficit. Although, it is possible that, this example may be of minor importance to the general European public, since Thailand is geographically distant.

Referring to foreign direct investment (FDI) and the importance of the EU as an export market of Thai products, there is a clear difference in economic partnership appreciation. Thailand is part of ASEAN is a gateway to China and, as such, does to some extent attract European economic interest. However, the figures indicate the higher dependency of Thailand on EU FDI and import. This suggests that the EU places emphasis on political and legal aspects during the negotiations, because its lower level of interdependence allows it to. This economic leverage is premised upon the fact that Thailand possesses less material power to negotiate on an equal footing with the EU. It also implies that, as the weaker negotiator, Thailand is more likely to concede and compromise. Perceived power asymmetries have the ability to influence the negotiations as seen in the case of the EU-ACP agreements. The Cotonou Agreement was quasi-instantly accepted after 18 months of negotiation. The Cotonou Agreement shows that the results

confirm that the weak can win a good deal, not necessarily in comparison with their endless growing needs, but in more relevant comparisons with what other rich states were doing, or with what the weak states had before, or with various initial points in the negotiations. ${ }^{16}$

In negotiations where the EU appears to be the only viable partner or offers financial incentives, the EU has higher chances to get its will and shorten the bargaining phase. Getting one's own will, that is, being able to win the maximalist position is a sign of negotiation power. Zartman further argues

[e]xpecting to lose a weaker party should want to avoid negotiation with a stronger party at all costs, but it cannot; and, expecting to win, a stronger party should have no need to negotiate to get what it wants, but it must. Yet weak parties not only engage stronger ones in negotiation, they usually emerge with payoffs - and often with bigger payoffs- in the end. ${ }^{17}$

Power symmetry may be a premise for optimal results for both sides, however, the ACP case indicates that weaker states may concede but benefit in higher proportions than the status quo or by being a tough negotiating partner. The Cotonou Agreement also demonstrates the significance of geographical proximity in the case of Africa and the disinterest of other big powers in early 2000. Unlike the African ACP countries, Thailand is further away and not of immediate interest. It is more developed and embedded in various institutional structures on the regional level such as ASEAN,

${ }^{16}$ Zartman, op. cit., p. 28.

${ }^{17}$ Ibid., p. 100. 
ASEAN Plus Three (APT), Asia-Pacific Economic Cooperation (APEC) or Bay of Bengal Initiative for Multisectoral Technical and Economic Cooperation (BIMSTEC) that include regional powers such as China and India. The multiple institutional memberships of Thailand enhance its bargaining power and attraction for cooperation. The memberships raise Thailand's profile in the eyes of the EU, but, also imply that the EU is not the only external partner of interest to Thailand. An EU official argues

This is my personal perception, that we are still pygmies in the region in the overall sense. If ASEAN was to choose who to negotiate with: EU, US or China. EU would be last. The EU is not the main flavour on the map. ${ }^{18}$

The aspect of alternative partners can be identified as a tactic of relatively weak states in negotiation with stronger partners and be added to Zartman's list of identified tactics. ${ }^{19}$ The impression that Thailand's bargaining power partially stems from its institutional memberships and bilateral relations is restated by the interviewed EC officials. However, this perception is not necessarily endorsed by some Council officials, who have argued more in line with the EU's economic leverage. Given their diverging standpoint, the understandings of power between the supranational and intergovernmental EU institutions differ and hint at the ideational and conceptual disparities among EU bodies that affect the external representation of the EU in general.

In view of the various memberships and its ties with China and the United States of America (USA), Thailand can draw on a variety of negotiation partners that are of higher priority to it than the EU. This perception is understandable, but may also be derived from imperfect, or even manipulated, information. Zartman explains

Thus, a third assumption is imperfect information, with the amount of information and its veracity under control of the parties involved. Indeed, since negotiation is by nature a communications encounter, not a physical encounter (like war) or a mechanical encounter (like voting) or some other sort, the controlled exchange of partial information is the very essence of its decision-making process....In the verbal and nonverbal exchanges that comprise negotiation, information is manipulated for the purpose of changing the other party's evaluation of the values involved, in order to bring about convergence or agreement at a point more favourable to one side than to the other. Power is defined as the volitionally controlled ability of one party to produce such movement or re-evaluation on the part of the other party, often more generally as the ability of one party to cause another to change behaviour in an intended direction. 20

The argument of manipulation or deception is not limited to information. It includes the use of gestures or playing pretend of power to impact the counterpart's selfesteem and have him/her call into question his/her own power. In view of the Commission officials' perception, Zartman's quotation suggests that Thailand's

\footnotetext{
${ }^{18}$ Interview with EU official, DG RELEX (now External Action Service), 20 November 2009, Brussels, conducted by the author.

19 Zartman, op. cit., pp. 112-3.

20 Ibid., pp. 40-1.
} 
toughness may be a product of manipulated information-sharing or exaggeration of the roles of other states as a means to compel the EU to compromise. Are the alternative partners of ASEAN, India, Japan, China and the USA that relevant for Thailand to be able to resist the PCA?

Comparative FDI and exporting figures demonstrate that the EU is a substantial driver of Thailand's economic growth, although the Thai side's tough negotiation stance may suggest otherwise. ${ }^{21}$ Thailand's negotiators have seemingly behaved consistently autonomous of Thailand's power position and exhibited considerable negotiation skills, thereby insinuating that the EU-Thailand PCA negotiations are sealed from the relative power distribution in the international system. ${ }^{22}$

This is reminiscent of Jürgen Habermas' ideal speech situation which requires, among other factors, that both actors recognise each other as equals and be "open to being persuaded by the better argument." 23 In these negotiations this appears partially true, since on cultural and political matters it is difficult to discern what is a better argument. Better arguments are subjective and, therefore, socialisation, implying the cognitive understanding of where the counterpart comes from, plays an essential role in the dialogue's progression. However, this does not qualify the better argument to win. Convergence is sometimes based on irrational grounds as featured in the potential solutions of the clause on the Rome Statute of the International Criminal Court (ICC) below. Concessions can stem from the empathy to compromise for the mutual benefit without needing to share the same lifeworld ${ }^{24}$. An EU official says

this is basically what negotiation is all about. It is not about exchanging positions but about exchanging flexibilities and I think we have seen this

\footnotetext{
${ }^{21}$ Thailand Board of Investment, op. cit. and Thailand Customs Department, Thailand Customs Department,

International Trade: Export and Import of Merchandise Goods, Bank of Thailand: $<$ http:// www2.bot.or.th/ statistics/ BOTWEBSTAT.aspx?reportID=52\&language=ENG $>$ accessed 22 March 2010.

22 Interview with EU official, EU Delegation to Thailand, 5 December 2009, Bangkok, conducted by the author.

${ }^{23}$ T. Risse, "'Let's Argue!", Communicative Action in World Politics.' International Organization, Vol. 54, No. 2, Winter 2000, p. 7.

24 The pursuant explanation is cited from Naila Maier-Knapp's article A Friend in Need. A Friend in Deed? ASEAN-EU Interregionalism in the light of Non-Traditional Security Crises in Southeast Asia in the Austrian J ournal of Southeast Asian Studies (3/ 1) 2010 and is based on J ürgen Habermas' book The Theory of Communicative Action: Lifeworld and System published by Polity in Cambridge in 1987: J ürgen Habermas argues that the social actors who interact dialectically by seeking mutual understanding of the situation, intention and action in order to agree to a reasoned consensus as the goal of the interaction must share a Lebenswelt (lifeworld). Habermas defines lifeworld in his book on The Theory of Communicative Action: Lifeworld and System from 1987 as "the transcendental site where speaker and hearer meet, where they can reciprocally raise claims that their utterances fit the world (objective, social, or subjective), and where they can critici[s]e and confirm those validity claims, settle their disagreements, and arrive at agreements....[S]peakers and hearers come to an understanding from out of their common lifeworld about something in the objective, social, or subjective worlds". When communicating, the actors make truth or validity claims and refer to the common lifeworld as their source of justification. Depending on the degree of divergence of the lifeworlds, international actors will find it easier or harder to come up with a shared normative preunderstanding in order to establish an arena for meaningful interaction and a deep and long-term cooperation.
} 
on the Thai side. Maybe it is fair to say that there were more flexibilities when Thaksin was still prime minister. ${ }^{25}$

Thailand's persistence on its interests has hardened post-coup. The constituency's disunity and discontent, have curbed the willingness of civil servants to make autonomous and fast decisions. Former Foreign Minister Noppadon Pattama's removal due to his signing of the Preah Vihear Temple declaration with Cambodia that bypassed endorsement by the Thai Parliament added to this fear. The ongoing domestic problems, which suggest a potential weakness of authority within Thailand have not destabilised the staunch way Thailand defends its interests in the negotiations. Rather they have reinforced its this approach. In this way, Thailand's domestic problems have had an adverse effect on the negotiations.

A central issue in the negotiations is the Rome Statute of the ICC. It has been signed by Thailand but remains unratified. In Thai society, the status of the king as the head of state is incontestable and the mere possibility that the king could be cited to the ICC presents a lèse majesté. In spite of the minimal likelihood for such a case to occur this goes against both Thailand's legal and cultural identity. Thailand has little room to negotiate. The EU possesses higher flexibility on this and may concede to this article being located outside the PCA framework, but such a concession would undermine European normative identity. Given that Thailand signed the Statute, this issue further questions Thailand's general adherence to fundamental principles of equality and freedom. It is questionable whether Thailand's official human rights and democracy commitments are meaningful or merely rhetorical declarations lacking true societal entrenchment. Furthermore, the impression could be that they are strategically used to serve the economic agenda in the dialogues with the Western world. 26

Negotiation to include the clause on the ICC into the PCA is in a deadlock. The Thai side cannot move from its position and the EU has comprehended this and signalled its willingness to reconsider and reword this topic.

I think the EU is realistic enough to see they need to compromise...on the other hand, the EU still wants to yield the overall objective that is to support the ICC in the wider world....On language there are ways out. ${ }^{27}$

Whether this deadlock will be resolved by a side letter or a joint declaration outside the PCA framework remains unclear for the time being. In fact, the European side is still attempting to embed the solution within the agreement. The resolution of this problem could be a matter of empathy.

Article 3 of the PCA concerning Weapons of Mass Destruction (WMD) formulates, inter alia, the respect for international commitments of non-proliferation. Consequently, the PCA would tie Thailand to certain international institutions perverting Thai law and Thailand's freedom to acquire nuclear power in the future. A

${ }^{25}$ Interview with EU official, DG RELEX (now External Action Service), 19 November 2009, Brussels, conducted by the author.

${ }^{26}$ G. Manea, 'Human Rights and the Interregional Dialogue between Asia and Europe: ASEAN-EU Relations and ASEM,' The Pacific Review, Vol. 21, No. 3, 2008.

${ }^{27}$ Interview with EU official, DG RELEX (now External Action Service), 19 November 2009, Brussels, conducted by the author. 
representative of the Council admitted that the Thai side has the higher moral ground in this regard because the EU consists of member states which have WMD. ${ }^{28}$ In this case again, the Thai side wishes the EU to reword the article. Problems of clear wording of legal and political articles based on mutual understanding have appeared to be problematic throughout the process, because once these articles are agreed on, Thailand is bound to them.

On the previous issues, the EU has shown flexibility and expressed the possibility to consider rewording the clauses, but, in terms of Article 47 concerned with the obligation to "essential elements" such as democratisation, good governance and human rights among others, the EU appears inflexible. From the beginning of the negotiations, the EU insisted on this clause, which was deemed unnecessary by the Thai side. The Thai officials still argue that all components should be treated equally important and that the inclusion of these political elements does not reflect Thailand's economic prioritisation in this connection.

We feel it makes the negotiations tougher. And how I mean, it is sort of telling us that these elements are more important than the others, which we do not see as this is a comprehensive agreement. All the issues are important and there shouldn't be any issue that stands out. 29

The EU's persistence has given Thailand room to bargain by a trade-off strategy. Thailand would like to include anti-dumping and sanitary and phyto-sanitary issues into this article, because they feel that this reflects their priority in the relations with the EU. The EU is still perceived to be a "fortress" in the sector of agricultural imports by the Thai side. ${ }^{30}$

The problematic articles reflect a clash of expectations, cultural and legal systems. The negotiations illustrate a process where the expectations differ and the initial knowledge of one another is limited and is expanded during the course of time. The result of this process is a minimally shared lifeworld that provides the foundation for deeper socialisation and actual meaningful cooperation in the future. Once the agreement has been achieved and the sub-committees and joint committees are in place, socialisation beyond the initial stage of acquaintance is enabled and the likelihood of reciprocal influence increases. This view is advocated by the Europeans. The PCA does not require meaningful convergence to act as a stepping stone for the EU-Thailand integration. From a long-term perspective, the PCA may be subordinate to succeeding developments, but, because of its binding nature both sides will aspire to the best starting position for themselves. Whereas the Thai officials aim to have the final say on economic legalities, the EU is more interested in shaping the normative setting for future cooperation.

With regard to the agenda, power distribution in the international sphere is relevant for the interpretation of the negotiation and the EU's insistence on Article 47. The Thai side's tough stance suggests that negotiation skills and strategies of involved

${ }^{28}$ Interview with EU official, General Secretariat of the Council of the European Union, 12 November 2009, Brussels, conducted by the author.

${ }^{29}$ Interview with Thai official, Ministry of Foreign Affairs, 11 December 2009, Bangkok, conducted by the author.

30 Ibid. 
individuals are decisive in inch-by-inch negotiation resulting in a balanced and satisfactory agreement for both sides. Zartman has formulated

All of these elements of "success" lead back to the principles of skilful negotiation and to the fact that negotiators are human beings with greater or lesser skills and with fortuitous elements aiding or hindering them. The inability to theory[s]e [sic] on this level reinforces the continuing - if limited- usefulness of the principles approach. ${ }^{31}$

Thailand's highly skilled diplomats, geographical distance, membership in the various institutions in the Asia-Pacific and relations with other external powers seemingly compensate the EU's economic leverage in the negotiations. The question remains whether Thailand would have negotiated in the same manner if the PCA offered financial incentives. In fact, given the relationship asymmetry and the strong economic drive behind the Thai interests, there is a high probability that Thailand may have already agreed on the PCA, if there was a financial incentive offered by the EU.

Furthermore, the examples show that the negotiations have been dependent on domestic and international developments. In some of the above described cases it is clear that Thailand's domestic developments have impacted the course and content of the negotiations significantly. Contextual developments correlate to the content and shape its characteristics.

Noteworthy is that the EU's political consensus-based foreign policy culture and negotiation style differs from that of other external powers in Southeast Asia and may have contributed to the sense of equality apparent in the negotiations. The EU is more flexible than its state dialogue partners because it has learnt to be flexible and tolerant from within. 32

EU cognitive processes have also been influenced by its external dimension. The EU learnt from its long history of external agreements and its quest for legitimacy in the international sphere. Furthermore, from a HI point of view, the EU's external actorness has also produced the institutional history and memory that locks future negotiations in.

The EU is not weak, but, constrains its economic interests by its obvious-to-theworld value-laden identity which it can project in some negotiations. In other negotiations, it displays lesser normative actorness quality and a cost-benefit calculation with regard to economic gains. Thus, the EU has occasionally been accused of double standards or a preference for normative issues in negotiations with weaker parties. ${ }^{33}$ Despite some confusions on the EU's identity that such inconsistency conveys, the EU-Thailand PCA is a manifestation of the EU's role as a unique shaper and constructor of the international system.

31 Zartman, op. cit., p. 25.

${ }^{32} \mathrm{~A}$. Wiener, 'European Responses to International Terrorism: Diversity awareness as a new capability?', J ournal of Common Market Studies, Vol. 46, No. 1, J anuary 2008, pp. 195-218.

33 This point has been raised within various interviews conducted by the author with Track 1 and 2 representatives in Southeast Asia from October 2008- J une 2010. 


\section{Conclusions}

This article argues that both sides have entered into the dialogue with different expectations, which did not change in the course of the negotiations, but actually became entrenched. The analysis has shown that the EU's approach to Southeast Asia is primarily explained by HI. The article has also debated the difficulties experienced during the EU-Thailand negotiations. Constructivist and negotiation theory have been used to locate the challenges to the negotiations on the content and context levels. The main inhibitors for the negotiations are found on the domestic level.

From the outset of the negotiation process, the power asymmetry seemingly played a minor role in the actual bargaining process and its validity was traced only with regard to the EU's insistence on the political and normative dimension of the PCA content. In these cases, it appeared that the EU was aware of its economic leverage and pushed its inherent values and principles. The negotiations reflect a divergence in interest priorities that stem from the different environmental and domestic realities.

During the negotiation process, both parties have gained a greater awareness of the other. Although deliberations may have been hampered by possibly manipulated and limited information, the six years of negotiations have led to an increase in mutual understanding. This increased empathy has facilitated a greater degree of convergence in negotiations, in spite of the apparently divergent power positions between the two parties.

The PCA articles are vague and the majority of these clauses merely serve as a general bilateral legal reference. From a European perspective, they are not about bargaining immediate material gains but bargaining a good starting position for continuous cooperation in many fields. Negotiating legalities with the EU and sharing the PCA information with other PCA negotiating Southeast Asian states illustrates a possible impact on Southeast Asian regionalism. It holds the potential to catalyse and harmonise regional views and legal standards.

This article reinforces the EU's comprehensive approach and insistence on the political and normative agenda and, hence, the international academic debate on EU normative actorness. The EU will neither achieve a maximalist position nor be able to persuade or coerce Thailand to converge on all issues or truly internalise the EU's essential elements clause in the PCA. However, it will have collaborated on a joint legal framework that resembles an open door for a common lifeworld facilitating future bilateral cooperation that may be beneficial in other fora.

The constructivist-negotiation theory perspective on the process has crystallised two central conclusions. First, the EU behaves as an international and regional socialising force. In spite of being subject to various content-context obstacles, the 
negotiation process needs to be seen more as part of a larger socialisation process than a process of bargaining tangible interests, because Thailand is remote and economically of secondary importance. Second, the dominance of the economic rationale to analysing EU-Asia relations has been put into perspective. Based on the power asymmetry in the EU-Thailand relationship, the EU can choose whether or not to apply an economic rationale. 